\title{
Editorial introduction: managing the Indian economy
}

\author{
Anindya Sen
}

Published online: 23 May 2018

(C) Indian Institute of Management Calcutta 2018

Discussions of the performance of the Indian economy often tend to get bogged down in the rate of growth of real GDP per capita-whether on the average it is going up or down, what can be done to stimulate it, whether the long-term prospects of attaining a higher growth rate are bright or not, and so on. There is of course a parallel discourse that focuses on the distributive issues, with one set of writers highlighting how and why the benefits of a growing economy bypass certain parts of the population and the other set dismissing such concerns as coming from inveterate nay-sayers.

In the early years after independence, India had adopted a socialist framework where both these concerns got their due recognition, though the mechanisms put in place to address efficiency and equity issues did not deliver most of what was planned. Over time there was a gradual switch to decentralized market mechanisms without the government ever really relinquishing its control over the economy. Witness the breathless interest which still greets the budget speech every year. With markets penetrating most areas of economic activity and the government struggling to maintain its say both by overt and covert means, the management of the economy poses new and difficult challenges. There are conflicts not only

\footnotetext{
A. Sen $(\square)$

IIM Calcutta, Kolkata, India

e-mail: asen@iimcal.ac.in
}

between the government and the private sector, but also between different government bodies and regulatory authorities.

In the current issue on Managing the Indian Economy, I have tried to include some articles that provide insights into the functioning of the Indian economy both at the macro-level and at the sectoral level. The issue begins with two articles clarifying the balances to be reached between administrators of monetary and fiscal policy. The next article enumerates and evaluates the recent trends in India's trade policy. The fourth article devotes itself to the services sector of the economy, since the services sector accounts for a major chunk of the growth process. A fifth article traces the growth of the telecom sector in India and its prospects for future development.

In contrast to the synoptic view adopted by the earlier articles, the next one on the agriculture sector analyses one critical aspect of Indian agriculture- the role of farm size and diversification in determining farmer's total income from both farm and non-farm sources. Finally, since environmental issues are now having an impact on each of us every hour of the day, I have included a review of a book written by Sunita Narain, one of the foremost environmental activists in the country.

The current issue starts with a reflective view of the interaction between fiscal and monetary policies by Y.V. Reddy, who as a former Governor of the Reserve Bank of India is uniquely positioned to give us an 
insight into the fraught relationship between the government and the RBI. As he points out, policymaking often involves considerations that are not based on academic theories. His paper presents a practitioner's perspective of how the interface between fiscal and monetary policies evolved in India. There has always been a tussle between the fiscal needs of the government requiring accommodating monetary policy and the independence of the RBI. Part of the solution lay in the government voluntarily imposing certain restrictions on its own actions and partly on developing institutions to which the government could turn to in lieu of the RBI. Solutions which were worked out in certain contexts sometimes came under stress when new developments occurred, for example the large capital inflows in the early part of the century. These necessitated innovative ways of achieving fiscal-monetary coordination, e.g., through the Liquidity Adjustment Facility and Market Stabilization Scheme. In recent years, policy-making and academic theorizing seem to be converging, as the RBI's primary objective has been defined explicitly (maintaining price stability keeping in mind the objective of growth) and a Monetary Policy Committee has been appointed to provide technical help to the RBI.

The next paper by M. Govinda Rao analyzes important issues in Indian public finance in the context of the India's economic development. On the expenditure side, he shows that expenditures on interest payments, subsidies and transfers have crowded out spending on physical and social infrastructures. From a long-term perspective of utilizing the so-called demographic dividend, the bad news is that spending on education and healthcare is woefully inadequate. Prof. Rao puts the onus for this on the low levels of taxation apart from lopsided priorities. The low tax ratio is due to the exemption to agricultural incomes, widespread tax preferences due to multiple objectives loaded into tax policy, tax abuse by multinationals and poor tax administration.

The low tax collection is also the reason for the persistence of large deficits and debt. This consideration leads the author to delve into the relationship between fiscal and monetary policy, complementing the discussions in the first paper. Despite the enactment of fiscal responsibility legislation, containing the government deficits and debt has been a major challenge and the targets are diluted, new concepts created and repeatedly postponed. The paper argues that there is a strong case for creating a fiscal council by amending the FRBM Act and it is should be appointed by the Parliament and should be reporting to it as recommended by the Fourteenth Finance Commission. (Dr. Reddy throws his support behind this idea.) This is in contrast to the Fiscal Review Committee's recommendation according to which the Fiscal Council should be appointed by the Finance Ministry and should report to it.

In India, the growth of services has been accompanied by steady decline in the shares of manufacturing and agriculture. During 1960-2016, the share of services rose from 32.8 to $53.8 \%$, for an average rise of $0.9 \%$, the same as the average global rise. Rafiq Dossani, in his paper, points out that in India's case, services and manufacturing grew independently of each other for many years. This independence was in large part due to public policies that encouraged low value-added, capital intensive manufacturing through protectionist policies. This helps explain why both services and manufacturing were relatively low valueadded compared to other countries, such as China, that consciously sought to integrate the two sectors. Even today in India, the services sector and, to a lesser extent, manufacturing, are seen as independent engines of growth. The linkages between them are not recognized and addressed. Given this background, Dossani discusses policy-makers' options for promoting higher value-added services in India, what this means for the manufacturing sector, and the linkages between services and manufacturing.

Saikat Sinha Roy and Avigyan Sengupta trace the changes in India's trade policy regime in the larger context of India's changing development strategy. They emphasize the often-missed point that in the Indian case, trade policy and industrial policy were inextricably linked together. As India's development strategy changed from import substitution to outward orientation, the protectionist policies during "planning for industrialization" in an economy with binding foreign exchange constraint in the 1950s gave way to a relatively open economy with lesser barriers to trade. Trade policy till the 1970s primarily focused on regulating the utilization of foreign exchange through the use of quantitative restrictions. Restrictions were imposed on foreign ownership of firms operating in India and import of foreign technology using Foreign Exchange Regulation Act 1973. The policies toward 
the external sector reforms in India, which followed industrial decontrol, have moved in two directions: the reforms relating to tradeables and exchange rate reforms since the 1980s.

The process of change in the trade sector has been sequential over a relatively long period of time, the process being complemented by wide ranging policy shifts in other sectors of the economy. However, there is an evidence of rising non-tariff costs in India's trade sector. In addition, the process of trade policy changes has been reversed in the recent period, which is a cause for concern, especially in the context of improving competitiveness of tradeables and growing integration of the domestic economy with the world economy.

One striking feature of the present situation in the telecommunications industry is the dwindling relevance of voice and the growing importance of data. In their paper on the Telecom sector, Subhashish Gupta, Kalpana Tyagi and Rajkumar Upadhaya note that these are exciting times for telecommunications in India. On the one hand, recent years have witnessed the entry of one of the largest business houses in India into the cellular mobile services market on a large scale, leading to increased competition as well as mergers and acquisitions. On the other, exciting new technologies are being unveiled and technologies such as Internet of Things, big data, cloud computing, 5G and artificial intelligence are starting to get deployed. These developments raise huge concerns of privacy and net neutrality. The authors discuss these and other related matters. They also provide a short history of telecommunications in India and discuss technological issues, manufacturing, infrastructure and market development. The paper rounds off the discussion with a set of recommendations on policy-making.

Varun Kumar Das and A. Ganesh Kumar's objective is to analyze the role of farm size and diversification in determining farmer's total income from both farm and non-farm sources. Using data from NSS 70th Round Situation Assessment Survey, they estimate a $\log$ linear regression model that relates farmer's income to farm size, on-farm and off-farm diversification, and various other control factors representing farm, household and locational characteristics. This model is estimated for total income over the whole year and separately for the two seasons: kharif and rabi. The authors find that farm size has a negative relationship with farmer's income per capita after controlling for various factors. Their results also lend support to the hypothesis that there is an optimal level of diversification that maximizes farmer's income. The paper demonstrates that farmers on an average are already engaged in the optimal number of crops, but they are at sub-optimal level in terms of animal husbandry and non-farm activities. Improving famers' education levels is another policy intervention that can help raise their income levels.

Today, the state of the environment affects each of us, mostly in negative ways. Rather than attempting to present a summary of all the environmental issues facing the country, I have decided to include the review of a book which touches upon some of the significant environmental concerns that have been highlighted in recent years, from an activist's viewpoint. Runa Sarkar reviews Sunita Narain's “Conflicts of Interest -My Journey through India's Green Movement," which is an excellent summary of key environmental issues plaguing India and the response of government and industry since the 1980s. As the reviewer notes, the book covers a range of issues, including air pollution, waste, water pollution and water scarcity, climate change, biodiversity and the deleterious impacts of pesticide. Peppered with anecdotes, the objective of the book is to highlight the conflicts of interest that arise when dealing with these issues. The book misses out on some of the other environmental movements which have shaped the state of India's environment today. But Ms. Narain still manages to provide an interesting insight into some of the conflicts of interest that are concomitant with improving the environment.

As the articles included in this special issue of Decision make it abundantly clear, managing the Indian economy has never been an easy task. The articles provide the reader with insights into a number of aspects of the functioning of the Indian economy. While recounting the developments at the macro- and sectoral levels, the respective authors take care to highlight some of the negative implications of the paths that have been pursued. They suggest their own prescriptions, and the reader is invited to judge their suitability in the light of our past experience with policy-making. 